Orientalia Christiana Cracoviensia 5 (2013), s. 11-25

DOI: http://dx.doi.org/10.15633/ochc.1071

Ангел Николов

Софийский Университет Св. Климент Охридски

\title{
Преславский собор 893 г. в современной историографии
}

События, разыгравшиеся в Болгарии после удаления в монастырь постаревшего князя-крестителя Бориса-Михаила (852-889; † 907), в первые годы правления его сына Владимира-Расате (889-893), трудно поддаются реконструкции и их интерпретация часто вызывала споры в историографии. ${ }^{1}$ Это вполне закономерно, учитывая почти полное молчание на этот счет доступных сегодня византийских источников. Здесь мы постараемся рассмотреть единственное более подробное свидетельство относительно политики Владимира-Расате и его детронизации в 893 г., помещенное в составленной ок. 908 г. хронике немецкого летописца Регино (ум. 915), бывшего игумена Прюмского монастыря (892-899) в Лотарингии.

Под 868 г. Регино описал крещение болгар и удивительное благочестие Бориса-Михаила, который в конце концов «оставил земное царство, чтобы навеки царствовать с Христом на небесах; и, поставив на своем месте королем своего старшего сына, постригся, приняв одежду святого подвижничества, и стал монахом, предаваясь днем и ночью милосердию, бдениям и молитвам. Между тем его сын, которого он поставил королем, и кто далеко отступал своему отцу в ревности и деятельности, стал заниматься грабежами, проводить время в пьянстве, пиршествах и разврате, и всеми средствами призывал свой новопокрещенный народ обратно к языческому обряду. Когда отец услышал об этом, воспламенившись сильным гневом,

${ }^{1}$ И. Дуйчев, Българско средновековие. Проучвания върху политическата и културната история на средновековна България, София 1972, с. 357-364; П. Стефанов, Юлиан Отстьпник и Владимир-Расате, [в:] 1100 години Велики Преслав. Т. 1. Отг. ред. Т. Тотев. Шумен 1995, с. 227-239; И. Илиев, Управлението на княз Расате (Владимир) (889-893). Един неуспешен опит за европейска преориентация във външната политика на България, [в:] Средновековна християнска Европа: Изток и Запад. Ценности, традиции, общуване, София 2002, с. 407-410. 
он снял с себя монашескую одежду, и надел опять военный пояс, и, одетый в королевскую одежду, присоединив к себе (людей) боящихся Бога, погнался за сыном, которого без затруднений скоро схватил, выколол ему глаза и послал его в тюрьму. Потом, созвав все свое королевство, поставил королем младшего сына, пригрозив ему перед всеми, что с ним случится то же самое, если он чем-нибудь уклонится от правового христианства. Распорядившись делами таким образом, сняв пояс и надев снова монашескую одежду, войдя в монастырь, (он) провел остаток своей нынешней жизни в святом подвижничестве.» ${ }^{2}$

В историографии ХІХ в. к приведенным уникальным сведениям Регино о болгарских событиях относились с более или менее открытым сомнением, поскольку их достоверность нельзя было проверить ${ }^{3}$ : уцелевшие византийские и средневековые славянские источники (за исключением т. наз. «Чуда св. Георгия о болгарине» ${ }^{4}$ ) очень смутно повествуют или вовсе не

${ }^{2}$ Reginonis abbatis Prumiensis Chronicon cum continuatione Treverensi, Recognovit Fr. Kurze. Hannoverae 1890, p. 96: «divina inspiratione commonitus regnum terrenum dimisit, ut in caelis aeternaliter regnaret cum Christo; et ordinato in suo loco regem filium suum maiorem natu, comam capitis deposuit habituque sanctae conversationis suscepto monachus effectus est, elemosinis, vigiliis et orationibus die noctuque intentus. Interea filius eius, quem regem constituerat, longe a paterna intentione et operatione recedans predas coepit exercere, ebrietatibus, comessationibus et libidinibus vacare et omni conamine ad gentilitatis ritum populum noviter baptizatum revocare. Quod cum pater audisset, nimio zelo accensus sacrum habitum deposuit et militiae cingulum resumpsit et cultu regio indutus, adsociatis sibi Deum timentibus, filium persecutus est: quem mox absque difficultate coepit, occulosque eius effodit, et in carcerem misit; deinde convocato omni regno suo filium iuniorem regem constituit, interminatus coram omnibus, similia fore passurum, si in aliquo a recta christianitate deviaret. His ita patratis, deposito cingulo et resumpto sanctae religionis habitu in asterium ingressus in sancta conversatione reliquum vitae presentis tempus duxit.»

${ }^{3}$ P. Šafařjk, Slowanské starožitnosti. Oddjl děgepisný, Praha 1837, с. 593; С. Палаузов, Век болгарского ияаря Симеона, Санкт-Петербург 1852, с. 27-28; К. Иречек, История болгар, Одесса 1878, 196-197, прим. 13; М. Соколов, Из древней истории болгар, СанктПетербург 1879, с. 126-127, 220-222 (текст и перевод). Характерно, что некоторые историки этого периода вообще не упоминают о Регино (см. напр. М. Дринов, Южные славяне и Византия в Х веке, «Чтения в Императорском Обществе Истории и Древностей Российских при Московском Университете» 1875 № 3, с. 5, прим. 20) (переп.: М. Дринов, Избрани съчинения. Т. І. Трудове по българска и славянска история, София 1971, с. 439). С подчеркнутым доверием относится к сведениям немецкого хрониста Е. Е. Голубинский (Е. Голубинский, Краткий очерк истории православных изерквей Болгарской, Сербской и Румылской или Молдо-Валашской, Москва 1871, с. 254). См. также обзор литературы у: Ю. Трифонов, Достоверен ли е разказът за ослепяванет на Борисовия син Владимир?, «Училищен преглед» XXVI (1927) № 5-6, с. 864-890 (оттд. оттиск., с. 10).

${ }^{4}$ Составитель «Чуда» описывает снятие Владимира его отцом Борисом-Михаилом таким образом: «И пока он был еще жив в монашестве, и вместо него [князем] был Владимир, его первый сын, благословение Божие и Михаилово было на Симеоне, и он занял престол, прогнав брата.» Здесь ограничимся перечислением более ранних изданий текста по разным спискам: Филарет, Кирилл и Мефодий, славянские просветители, «Чтения в Императорском 
упоминают о свержении Владимира и восшествии Симеона. Учитывая эти обстоятельства, можно понять почему интересующее нас выражение Регино «созвав все свое королевство» первоначально не привлекло внимание исследователей. Однако следует отметить, что в первой части своих «Писем об истории сербов и болгар», напечатанной впервые в журнале «Московская беседа» в 1854-1855 гг., А. Ф. Гильфердинг (1831-1872) впервые выдвинул идею, что немецкий хронист имел ввиду не что иное, как именно созыв собора. В его вольном переводе слова Регино звучат так: «потом, созвав собор от всего своего государства, поставил королем своего меньшего сына.» ${ }^{5}$

Работая над второй частью первого тома своей масштабной «Истории болгарского государства в средние века» Васил Златарски (1866-1935) уделил немало внимания сведениям из немецкой хроники. В 1925 г. он опубликовал статью, в которой характеризировал Регино как «одного из наиболее добросовестных западных хронистов» и недвусмысленно отдал предпочтение именно ему, а не греческим источникам (Житию 15-ти Тивериупольских мучеников и Пространному греческому житию св. Климента) при реконструкции событий 893 г., поскольку в последних «умышленно избегалось упоминать о поступке Бориса, так как это опятнило бы его святость, которую они воспевали.» ${ }^{6}$

Далее Златарски утверждал, что под выражением «convocato omni regno suo» современника «надо, очевидно, понимать, что Борис созвал народный собор. Будучи одной из форм управления, народный собор...,

Обществе Истории и Древностей Российских при Московском Университете» 1846 № 4, с. 5, прим. 10 (переп. в: Филарет, Историческое учение об отцах изеркви, Т. I, Санкт-Петербург 1859, с. 355; Кирилло-Мефодиевский сборник. В память о совершившемся тысящелетии славянской письменности и христианства в России, изданный М. Погодиным, Москва 1865 , с. 48); И. Срезневский, Дополнения к общему повременному обозрению древних памятников русского письма и языка, II, «Известия Императорской Академии наук по Отделению Русского Языка и Словестности», Т. 10. Санкт-Петербург 1861-1863, стб. 672-673; Х. Лопарев, Чудо Святого Георгия о болгарине. Памятник византийской, переводной, литературы, Санкт-Петербург 1894, с. 20 (Памятники древней письменности ИОЛДП, 100). Современный анализ рукописной традиции, авторства и датировки текста: А. Турилов, К изучению Сказания инока Христодула: датировка ичикла и имя автора, [в:] Florilegium. К 60-летию Б. Н. Флори. Москва 2000, с. 412-427; А. Турилов, «Мъдра Пльсковская» и «Мъдра Дръсторская»-две Мундраги первой болгаро-венгерской войнь (география чудес вмч. Георгия в Сказании инока Христодула), [в:] Славяне и кочевой мир. К 75-летию акад. Г. Г. Литаврина, Москва 2001, с. 40-58 (Славяне и их соседи, 10).

${ }^{5}$ А. Гильфердинг, Собрание сочинений, Т. І., Санкт-Петербург 1868, с. 86.

${ }^{6}$ В. Златарски, Страниции из старата културна история на българите, [в:] Сборник в чест и в памет на Луи Леже 1843-1923, София 1925, с. 284-285, прим. 3. Ср. В. Златарски, История на българската държава през средните векове. Т. І. История на Първото българско ияарство, Ч. 2. От славянизацията на държавата до падането на Първото царство (852-1018), Под ред. на П. Петров, София 1971, с. 255. 
который первоначально состоял из всего вооруженного болгарского народа во главе с боилами или болярами, существовал, как известно, и в языческой Болгарии и играл роль верховной власти, которая стояла выше главы государства [...] Однако с усилением центральной власти с начала IX в. [...] и особенно после принятия христианства, когда абсолютизм получил через церковь полную санкцию [...] народный собор потерял свой первоначальный характер и превратился в совещательное тело, причем только в чрезвычайных ситуациях. Если Борис нашел необходимым созвать в 893 г. народный собор со всего царства, в состав которого входили по византийскому образцу наряду с духовенством и болярством - малым и великими, еще и представители со всех областей государства, то это показывает, что и вопросы, которые надо было предложить этому собору, были первостепенной важности, касались всей государственной жизни, и потому нуждались в всенародном одобрении.» ${ }^{7}$

Установив таким образом, что формальное лишение Владимира власти и провозглашение третьего сына Бориса-Михаила произошло именно на народном соборе, Златарски указал и место его проведения - Преслав, где согласно Болгарской апокрифической летописи Симеон «принял царство.» ${ }^{8}$ Согласно концепции В. Златарского, на том же соборе новый князь (по замыслу своего отца) «всенародно объявил», что столица переносится из Плиски, где «все еще упорно держались языческие обычаи и нравы», в Преслав, где Симеон мог окружить себя личностями, вполне преданными христианству, которые «искренне усвоили славянскую (т.е., славянизаторскую - прим. А. Н.) политику Бориса и примирились с идеей об абсолютном самодержавии.» ${ }^{9}$

Но В. Златарски не остановился на этом - основываясь на смутных русских известиях о «преложении книг», которое произошло через 30 лет после крещения болгар, через 77 лет после Седьмого вселенского собора, а от Адама в 6406 г., он утверждал, что в 893 г. ученики Мефодия в Болгарии закончили перевод богослужебных книг, в результате чего на народном соборе в Преславе «был отброшен греческий язык и народный славяноболгарский язык был провозглашен официальным в государстве, а в церкви было решено ввести славяноболгарские книги и богослужение.» ${ }^{10}$

Предложенная В. Златарским реконструкция, хотя и имела некоторую научную ценность, основывалась преимущественно на косвенных данных и допущениях и ее следовало бы воспринимать как удачную гипотезу. Тут нужно отметить, что она обязана своим появлением в немалой степени

\footnotetext{
${ }^{7}$ В. Златарски. Страници...., с. 285-286; Златарски, В. История... I/2, с. 256-257.

${ }^{8}$ В. Златарски, Страници..., с. 286; Златарски, В. История... I/2, с. 257-258.

${ }_{9}^{9}$ В. Златарски, Страници..., с. 287; Златарски, В. История... I/2, с. 258-259.

${ }^{10}$ В. Златарски, Страници ..., с. 288; Златарски, В. История... I/2, с. 261.
} 
соображениям и причинам сугубо вненаучного характера - в середине 20 -х годов XX в. в Болгарии назревала инициатива торжественно отметить 1000 -летие Симеоновой эпохи, причем В. Златарски очень активно участвовал в работе по организации и проведению намеченных чествований. Страна, недавно перетерпевшая катастрофическое крушение своих вожделений в ходе Первой мировой войны, была охвачена острым экономическим кризисом и кровавыми политическими настроениями. В этот период в кругах политической и культурной элиты наметилось стремление успокоить общество и сплотить его вокруг монархии, как воплощения религиозных и национальных ценностей, уходящих корнями к древним традициям болгарской государственности.

Вышедшая в свет в 1927 г. вторая часть первого тома монументальной «Истории болгарского государства в средние века» В. Златарского, где дословно воспроизводились постулаты о Преславском соборе, изложенные впервые в его статье 1925 г., стала идейной основой планировавшегося юбилея. Впрочем, хотя эти постулаты и были изложены в нескольких его статьях тех лет ${ }^{11}$, в своей речи «Государственно-политические идеи царя Симеона», произнесенной на торжественном собрании в Академии наук 14 мая 1929 г., В. Златарски воздержался даже от упоминания собора 893 г., хотя в очередной раз связал т. наз. «национализацию болгарского государства и церкви», т. е. введение славяно-болгарского языка в государстве, церкви и школе, с началом царствования Симеона. ${ }^{12}$

Официальные государственные празднования 1000-летия царствования Симеона, невиданные по своему размаху и щедро профинансированные правительством ${ }^{13}$, состоялись 12 мая 1929 г. возле развалин средневековых дворцов в Преславе, где была освящена новая церковь св. Кирилла и св. Мефодия и прошел военный парад, потом среди недавно обнаруженных археологами руин круглой церкви В. Златарски говорил об эпохе царя Симеона ${ }^{14}$, а на последовавшей «народной трапезе» слово произнес сам царь Борис III (1918-1943). ${ }^{15}$ Примечательно, что зажженный при освящении новой церкви «священный огонь древних болгарских царей»

${ }^{11}$ V. Zlatarski, The Making of the Bulgarian nation (II), «The Slavonic Review» 4 (1926) № 12, p. 640-644; В. Златарски, Образуване на българската народност, «Българска историческа библиотека» I (1928) T. I, с. 107-110.

12 Златарски, В. Държавно-политическите идеи на изар Симеона, «Летопис на Българската академия на науките» ХІІ (1928/1929), София 1931, с. 195.

${ }^{13}$ Централен държавен архив - София, Ф. 3 к, Оп. 1, а. е. 1189, л. 20 (Постановление Министерского совета от 12 апреля 1929 г., которым на финансирование торжеств уделено 800000 левов).

${ }^{14}$ Помен за миналото, урок за настоящето, «Зора» X (15 V 1929) № 2959, с. 1.

${ }^{15}$ Централен държавен архив - София, Ф. 3 к, Оп. 1, а. е. 1189, л. 21-22 (программа чествований), с. 41-43 (речь царя). 
был перенесен эстафетой «целокупной болгарской молодежи, объединенной в родные спортивно-гимнастические организации» через всю страну в Софию. В свою очередь 14 мая 1929 г. состоялось торжественное открытие нового здания Болгарской академии наук и на проведенном в связи с этим торжественном собрании в присутствии царя В. Златарски прочитал вышеупомянутую речь о государственно-политических идеях царя Симеона. ${ }^{16} \mathrm{~B}$ день церковного поминовения св. князя Бориса-Михаила 15 мая 1929 г. огонь был встречен царем в болгарской столице, а потом по улицам города прошли многолюдные факельные шествия в ознаменование 50-летия освобождения страны от турецкой власти и 10-летней годовщины восшествия Бориса III на престол. ${ }^{17}$

Исключительный (и надо отметить - вполне заслуженный) научный авторитет и личное человеческое обаяние В. Златарского, наряду с наложенной на его труды «печатью высочайшего одобрения», обусловили популярность его гипотезы о решениях собора 893 г. не только в болгарской, но и в зарубежной историографии. В 1930 г. британский византинист Ст. Рансиман (1903-2000) в своей «Истории Первого болгарского царства» (посвященной царю Борису III) воспроизвел основные постулаты В. Златарского, преподнеся их своим читателям как неподлежащий сомнению факт. ${ }^{18}$

О начертанной В. Златарским общей картине событий 893 г. очень положительно отозвался и знаток древнеболгарской литературы Г. А. Ильинский (1876-1937); он, однако, полагал - а подобную гипотезу немного ранее высказал и П. Лавров ${ }^{19}$ - что выражение «преложение книг» обозначает решение собора заменить глаголицу кириллицей, составленной пресвитером

${ }^{16}$ В своем выступлении на этом собрании председатель академии Л. Милетич витиевато отмечал, «что открытие нового академического здания [...] происходит в торжественные дни, когда мы чествуем тысячелетнее историческое прошлое Болгарии. [...] В этом храме болгарской науки сегодня воздастся славохваление (sic!) тысячелетнего упорного хода болгарского национального гения, который, в непрестанной борьбе со злыми духами вечных противников всего болгарского, неуклонно отстаивал культурные заветы предков» - Реч на председателя на Академията проф. Л. Милетич, «Летопис на Българската академия на науките» Т. XII (1928/ 1929), София 1931, с. 191. См. также: Тържественото заседание на Академията на науките, «Зора» X (16 V 1929) № 2960, с. 3.

${ }^{17}$ Князь Борис Тырновский стал царем после вынужденной абдикации его отца Фердинанда (1887-1918) 3 октября 1918 г. в связи с развалом фронта на Добром поле в Македонии, капитуляцией Болгарии и начавшимся походом взбунтовавшихся войсковых подразделений на Софию.

${ }^{18}$ S. Runciman, A History of the First Bulgarian Empire, London 1930, p. 134-136. Нельзя не согласиться с оценкой А. Брайера, что в этой книге С. Рансиман старательно воспроизводит некоторые из неточных представлений Златарского (А. Bryer, James Cochran Stevenson Runciman, [in:] Byzantine Style, Religion and Civilization. In Honour of Sir Steven Runciman, ed. by E. Jeffreys, Cambridge 2006, p. XLIX).

19 П. Лавров, Кирило та Методій в давньо-слов'янському письменстві (Розвідка), Київ 1928, с. 205. 
Константином Преславским по воле князя Симеона, «стремившегося посредством новой, гораздо более простой и более легко усваиваемой азбуки облегчить и ускорить процесс славянизации болгарской церкви и государства. $\rangle^{20}$

Здесь нет возможности проследить детально, как гипотеза В. Златарского о решениях собора 893 г. прочно укоренилась в трудах по истории и литературе средневековой Болгарии, превратившись в своеобразную аксиому. ${ }^{21}$ Однако еще в свое время П. Мутафчиев (1883-1943) предупреждал о полной произвольности «очень распространенного у нас мнения», что на этом соборе было решено объявить славяноболгарский официальным языком в государстве и церкви. ${ }^{22}$ В последние десятилетия некоторые авторитетные исследователи вовсе не упоминают о таком соборе, стремясь порвать с тенденцией некритического восприятия слабо обоснованных

${ }^{20}$ Г. Ильинский, Где, когда, кем и с какою целью глаголица была заменена «кириллицей»?, «Byzantinoslavica» III (1931), c. 87. Ср. подобные догадки, высказанные напоследок А. Алексеевым (А. Алексеев, Текстология славянской библии, Санкт-Петербург 1999, c. 160-161), а также возражения на этот счет (Т. Славова, Глаголическата традиция и Преславската книжнина, «Palaeobulgarica» XXIII (1999) № 1, с. 35-46; А. Николов, Политическа мисъл в ранносредновековна България (средата на IX - края на Х век), София 2006, с. 191, прим. 15). См. также Е. Георгиев, Разиветът на българската литература в IX-X в., София 1962, с. 72-73 (автор считает, что на соборе в 893 г. глаголица была заменена кириллицей, которая по его мнению была более старинной письменной системой и ее создателем нельзя считать Константина Преславского).

${ }^{21}$ S. Bobcev, Bulgaria under Tsar Simeon - II, «The Slavonic and East European Review» 8 (1929) № 22, p. 106; D. Obolensky, The Bogomils. A Study in Balkan Neo-Manichaeism, Cambridge 1948, p. 87; G. Soulis, The Legacy of Cyril and Methodius to the Southern Slavs, «Dumbarton Oaks Papers» 19 (1965), p. 25; В. Гюзелев, Княз Борис I. България през втората половина на IX в., София 1969, с. 470-476; D. Obolensky, The Byzantine Commonwealth. Eastern Europe, 500-1453, London 1971, p. 97; F. Milkova, Les réunions du peuple en tant qu'institution de l'État bulgare médiéval, «Études Balkaniques» 1978 № 4, p. 115-122; М. Каймакамова, Старобългарската летописна традиция и «Повесть временных лет», [в:] Българско средновековие. Българосъветски сборник в чест на 70-годишнината на проф. Иван Дуйчев, София 1980, с. 214-215; Д. Ангелов, Образуване на българската народност. Второ преработено и допълнено издание, София 1981, с. 253-254; История на България, Т. ІІ. Първа българска държава, София 1981, c. 237-238, 270; J. V. A. Fine Jr., The Early Medieval Balkans. A Critical Survey from the Sixth to the Late Twelfth Century, Ann Arbor 1983, p. 130-131; И. Добрев, Кирило-методиевите ученици през първите години след пристигането им в България (886-893), [в:] Изследвания по кирило-методиевистика, София 1985, с. 155-159; Е. Александров, Интронизирането на княз Симеон - 893 г., «Palaeobulgarica» XV (1991) № 3, с. 10-17; И. Калиганов, Болгарская литература, [в:] История литератур западных и южных славян, Т. І. Москва 1997, с. 112 (с акцентом на замену глаголицы кириллицей на соборе в 893 г.); И. Божилов, Гюзелев В., История на средновековна България VII-XIV век. София 1999, с. 224-225 (автор раздела - В. Гюзелев); F. Curta F. Southeastern Europe in the Middle Ages. Cambridge 2006, p. 177 (Cambridge Medieval Textbooks, 39). См. также прим. 27 ниже.

22 П. Мутафчиев, История на българския народ (681-1323, Под ред. на В. Гюзелев. София 1986, с. 177. 
и сильно идеологизированных по своей сути построений. ${ }^{23}$ Среди работ последних лет следует отметить статьи А. Бояджиева и К. Попконстантинова ${ }^{24}$, а также замечание Д. Полывянного о приписываемых собору 893 г. решениях: «С различных точек зрения может быть оспорена достоверность практически каждого из якобы принятых Симеоном решений, но безусловно отвергнуто, на наш взгляд, должно быть представление об их одновременности и одномоментности.»» 25

Несмотря ни на что, серьезная научная дискуссия по интересующей нас теме так и не состоялась, зато в кругах некоторых историков и филологов даже проявилась тяга как к защите старых положений В. Златарского, так и к их «обогащению» новыми «деталями». ${ }^{26}$ Так например, основываясь на беглом замечании И. Эксарха в его «Шестодневе», Й. Андреев считал, что именно собор 893 г. установил возможность перехода княжеской власти

${ }^{23}$ И. Божилов, Цар Симеон Велики (893-927): Златният век на средновековна България, София 1983; И. Божилов, Владимир (Расате), [в:] Кирило-Методиевска енциклопедия, T. I. София 1985, с. 449-450; J. Shepard, Symeon of Bulgaria-Peacemaker, «Годишник на Софийския университет. Научен центьр за славяно-византийски проучвания» «И. Дуйчев» 3 (1989), София 1991, p. 9-48; И. Божилов, Седем етюда по Средновековна история, София 1995; J. Shepard, Slavs and Bulgars, [in:] The New Cambridge Medieval History, vol. 2: c. 700 - 900, ed. by R. McKitterick, Cambridge 1995, p. 228-248; J. Shepard, Bulgaria: the other Balkan 'empire', [in:] The New Cambridge Medieval History. vol. 3: c. 900 - c. 1024, ed. by T. Reuter. Cambridge 1999, p. 567-585; А. Турилов, Борис, [в:] Православная энциклопедия, Т. VI. Москва 2003, с. 30-32; Д. Шепард, Неспокойни съседи. Българо-византийска конфронтация, обмен и съжителство през средните векове. Прев. Л. Генова, София, 2007. См. тоже Г. Николов, Централизъм и регионализъм в ранносредновековна България (края на VII-началото на XI век), София 2005, с. 112 (автор не стремится приписать собору какие-либо гипотетические решения), как и наш разбор событий 893 г. и посвященной им литературе, где осторожно проводится мысль об условности традиционных историографических построений (Николов, А. Политическа мисъл..., с. 115-123).

${ }^{24}$ А. Бояджиев, Св. Климент Охридски и кирилищата, [в:] Климент Охридски-живот u дело, София 2000, с. 86-111 (Кирило-Методиевски студии, 13). Автор убедительно оспаривает искуственно проведенную В. Златарским связь между собором 893 г. и «преложением книг». См. также: К. Попконстантинов, Прбложение кънигъ и гръикият език в средновековна България (по епиграфски данни), [в:] Византия - Балканите - Европа. Изследвания в чест на проф. В. Тъпкова-Заимова, София 2006, с. 413-422 (Studia Balcanica, 25).

25 Д. Полывянный, Культурное своеобразие средневековой Болгарии в контексте византийско-славянской общности IX-XIV веков, Иваново 2000, с. 45.

${ }^{26} \mathrm{Cм}$. например весьма фрагментарные и смутные заметки о событиях 893 г., разбросанные по разным разделам новейшей обзорной истории древнеболгарской литературы: История на българската средновековна литература, Съст. А. Милтенова. София 2008, с. 52 (епископское рукоположение Климента связывается категорически с собором в Преславе в 893 г., с ссылкой на К. Станчев, Г. Попов, Климент Охридски. Живот и творчество, София 1988, с. 41-42, где подобное утверждение директно не высказывается), с. 81 (реформы 893 г. описываются без какого-либо упоминания о соборе). 
не только от отца к сыну, но и от брата к брату ${ }^{27}$; Н. Драгова доказывала, что в Дуклянской хронике ${ }^{28}$ отразилось древнеболгарское свидетельство о деятельности собора и приписала ему решение о повороте Болгарии к Римской церкви ${ }^{29}$; в появившейся недавно книге А. Калоянова сделана попытка реконструировать «повестку дня» Преславского собора, однако выводы автора нельзя охарактеризовать никак иначе, как фантастическими. ${ }^{30}$

В 1993 г. на конференции, посвященной 1100-ой годовщине Преславского собора, Н. Кочев эмоционально отметил, что даже если отсутствовали какие-либо материалы о соборе в 893-894 г., историк должен предположить его созыв. ${ }^{31}$ Хотя В. Златарски прибегал иногда именно к этой логике и буквально «сотворил из ничего» свое описание никаким историческим источником не засвидетельствованного собора 918 г., анализ свидетельств Регино дает достаточные основания утверждать, что в 893 г. Борис-Михаил действительно созвал собор со всех концов своего государства. По крайней мере, именно это имел в виду немецкий летописец, хотя нам не известно откуда он почерпнул свою информацию о событиях в Болгарии ${ }^{32}$ и в какой мере приспособил ее к целям своего повествования и вкусам своих современников и читателей.

Тут следует отметить, что для франков в IX в. наказание лишением зрения было не варварским актом произвола, а специальной прерогативой и ярким проявлением легитимной императорской власти, почерпнутой из византийской практики. ${ }^{33}$ Не исключено, что именно ослепление нечестивого

${ }^{27}$ Й. Андреев, Народните събори в политическия жсивот на Първата българска държсава, «Исторически преглед» 1971 № 4, с. 100-101; Й. Андреев, Йоан Екзарх и някои въпроси във връзка с наследяването на ичарската власт в средновековна България, [в:] Преславска книжовна школа, Т. 1, София 1995, с. 308-316; И. Божилов, В. Гюзелев, История на средновековна България..., с. 225.

28 Љетопис попа Дукљанина. Увод, превод и коментар С. Мијушковић, Титоград 1967, c. $192-201$.

${ }^{29}$ Н. Драгова, Нов прочит на епископската титулатура на св. Климент, [в:] Българи в Италия и италианции в България. Приноси, София 1997, с. 69-96.

${ }^{30}$ А. Калоянов, Славянската православна ичивилизация. Началото: 28 март 894 г., Плиска, Велико Търново 2007.

${ }^{31}$ Н. Кочев, Народният събор в Преслав през 893/4 г., [в:] 1100 години Велики Преслав, Т. 1. Отг. ред. Т. Тотев, Шумен 1995, с. 52. Ср. Н. Кочев, Имало ли е Народен събор в Преслав през 893-894 г., «Духовна култура» 1993 № 4, с. 27.

${ }^{32}$ Правдоподобна, но недоказуема догадка И. Дуйчева, что сведения Регино о недостойном поведении и язычестве Владимира отражают тенденциозные слухи, распространившиеся на Западе через византийское посредничество или после низложения этого болгарского правителя (И. Дуйчев, Българско средновековие..., с. 360).

${ }^{33}$ G. Bührer-Thierry, «Just Anger» or «Vengeful Anger»? The Punishment of Blinding in the Early Medieval West, [in:] Anger's Past. The Social Uses of an Emotion in the Middle Ages, ed by B. Rosenwein, Ithaca 1998, p. 87, 89, 91. По мнению Дж. Херин, на Западе только вестготы сознательно имитировали византийский обычай ослепления политических 
правителя болгар его отцом-монахом привлекло внимание Регино. В истории Франкской империи было несколько случаев ослепления представителей властвующего рода Каролингов, самым впечатляющим из которых было ослепление в 873 г. Карломана, младшего сына короля западных франков Карла Плешивого, который пренебрег своим дьяконским чином, сбежал из монастыря и вступил в вооруженный конфликт со своим отцом. В свое время Ю. Трифонов предположил, что Регино умышленно сфабриковал свой рассказ об ослеплении Владимира его отцом и поместил его почти непосредственно перед эпизодом с ослеплением Карломана, чтобы убедить своих читателей в том, что это было справедливое наказание. ${ }^{34}$ Хотя тезис Ю. Трифонова о подложности рассказа об ослеплении Владимира притянут и недоказуем, логика исследователя повела его в правильном направлении: чтобы лучше понять болгарский сюжет Регино, нужно всмотреться в его хронику.

Оказывается, у немецкого хрониста были свои, и довольно веские причины проявить причастность и внимание к судьбе Владимира - будучи игуменом Прюмского монастыря, он принял под свое попечение и постриг в монахи ослепленного в 885 г. императором Карлом III Толстым (881-888) единственного (внебрачного) сына короля Лотаря II (855-869), Хуго, который попытался захватить силой королевство своего покойного отца. Хотя Регино довольно лаконичен в хронике, он несомненно предельно хорошо знал судьбу своего постриги, суд и приговор над которым был совершен императором в сентябре 885 г. на созванном в Франкфурте вероятно специально по этому поводу соборе. ${ }^{35}$

Практика частого созыва соборов или собраний (Reichsversammlungen, Hoftagen) более влиятельных светских и духовных лиц императорами была важным элементом франкской государственной традиции. Состав участников однако не был строго определен и зависел от обсуждаемых вопросов. Соответственно, сильно варьировались и термины, которыми обозначены эти соборы в дошедших до нас латинских источниках:

соперников, а правители из династии Каролингов, учитывая специфику франкской системы наследственного права, стали целенаправленно (хотя и редко) практиковать это наказание по отношению к взбунтовавшимся сыновьям или племянникам, которые оспаривали их власть: J. Herrin, Blinding in Byzantium, [in:] Polypleuros nous. Miscellanea für Peter Schreiner zu seinem 60. Geburtstag, Hrsg. von C. Scholz und G. Makris. München-Leipzig 2000, p. 56-68, особ. 67 (Byzantinisches Archiv, 19).

${ }^{34}$ Ю. Трифонов, Достоверен ли е разказът..., с. 26-28.

${ }^{35}$ Annales Fuldenses s. a. 885: «Imperator cum suis apud Francofurt colloquium habuit...» (Annales Fuldenses sive Annales Regni Francorum Orientalis, post ed. G. H. Pertzii recognovit F. Kurze, Hannoverae 1891, p. 103). О подробностях см. S. Maclean, Kingship and Politics in the Late Ninth Century. Charles the Fat and the end of the Carolingian Empire, Cambridge 2003, p. 149-150. 
conventus, placitum, concilium, colloquium, synodus. ${ }^{36}$ Если всмотреться в свидетельство Регино о ослеплении Владимира, мы убедимся, что выражение «convocato omni regno suo», тяготеет именно к терминологии, которой франкские историки описывали созыв государственных соборов своими императорами. Особенно разительное сходство с текстом Регино обнаруживает Моасакская хроника, в которой под 813 г. описан собор, созванный императором Карлом Великим: «И в том же месяце сентябре вышеназванный император Карл сделал большой собор народа со всего своего королевства или империи (de omni regno vel imperio suo) у дворца в Аахене. И собрались... епископы, игумены, графы и Сенат франков у императора в Аахене.» ${ }^{37}$

Учитывая изложенное, можно предположить, что Регино узнал откуда-то о интересующих нас событиях 893 г. и был впечатлен видимым сходством болгарских практик наказания ослеплением провинившегося князя и водворения справедливости и «чистоты христианства» на государственном соборе с подобными традициями у франков. Но нельзя отбросить и возможность альтернативной интерпретации - немецкий хронист мог украсить и дообработать в соответствии с вкусами и ожиданиями своих читателей первоначальную информацию об ослеплении Владимира его отцом, дополнив ее смутно обрисованным образом собора, символизирующего легитимность правления и гармонию между высшей властью и подданными.

\section{Резюме}

В статье рассматриваются события, разыгравшиеся в Болгарии в первые годы после удаления в монастырь постаревшего князя Бориса-Михаила при правлении его сына Владимира-Расате. Обсуждаемые события трудно поддаются реконструкции и их интерпретация часто вызывала споры и противоречия в историографии. Единственное более подробное свидетельство относительно политики Владимира-Расате и его детронизации

${ }^{36}$ D. Eichler, Frankische Reichsversammlungen unter Lüdwig dem Frommen, Hannover 2007, S. 7-28 и далее (Monumenta Germaniae Historica. Studien und Texte, 45).

${ }^{37}$ Chronicon Moissacense s. a. 813: «Et in ipso anno mense septimbrio iamdictus imperator Karolus fecit conventum magnum populi apud Aquis palatium de omni regno vel imperio suo. Et convenerunt ad eum episcopi abbates comites et senatus Francorum ad imperatorem in Aquis.» Цит. по новому изданию текста: $\mathrm{Ph}$. Buc, Ritual and Interpretation: the Early Medieval Case, «Early Medieval Europe» 9 (2000) № 2, p. 205, http://dx.doi.org/10.1111/1468-0254.00065, Cp. описание собора в Аахене, созванного Людовиком Благочестивым в декабре 818 г.: «Qua hieme imperator in eodem palatio conventum populi sui celebravit publicum et renuntiantes sibi missos de omni regno suo quos pro statu sanctae ecclessiae, restaurando deiecta vel confirmando stantia, miserat, audivit» (Vita Hludowici imperatoris, [in:] Monumenta Germaniae Historica. Scriptores, T. II. Hannoverae 1829, p. 624. 18-21). Об этом соборе: É. Lesne, Les ordonnances monastiques de Louis le Pieux et la Notitia de servitio monasteriorum, «Revue d'Histoire de l’Église de France» 6 (1920) № 32, p. 321-338. 
в 893 г., помещенное в составленной ок. 908 г. хронике немецкого летописца Регино, игумена Прюмского монастыря в Лотарингии, является предметом анализа данной статьи.

\section{Ключевые понятия}

Преславский собор; Регино Прюмский; Владимир-Расате; историография

\section{Abstract}

\section{The The Preslav Council of 893 in modern historiography}

In this paper the events that took place in Bulgaria in the first years after the removal of the monastery old prince Boris Michael, during the reign of his son Vladimir Rasate are discussed. The events are difficult to reconstruction and their interpretation often caused controversies and contradictions in historiography. The only detailed testimony concerning the policy of Vladimir Rasate and his dethronement in 893 is placed in the German chronicle compiled around 908 by Regino the abbot of the Prüm monastery in Lorraine which is the subject of the analysis.

\section{Keywords}

The Preslav Council; Regino of Prüm; Vladimir Rasate; historiography

\section{Библиография}

Александров Е., Интронизирането на княз Симеон - 893 г., «Palaeobulgarica» XV (1991) № 3, с. 10-17.

Алексеев А., Текстология славянской библии, Санкт-Петербург 1999.

Ангелов Д., Образуване на българската народност, Второ преработено и допълнено издание, София 1981.

Андреев Й., Народните събори в политическия живот на Първата българска държава, «Исторически преглед» 1971 № 4, с. 100-101.

Андреев Й., Йоан Екзарх и някои въпроси във връзка с наследяването на иарската власт в средновековна България, [в:] Преславска книжовна школа, Т. 1., София 1995 , с. $308-316$.

Божилов И., Цар Симеон Велики (893-927): Златният век на средновековна България, София 1983.

Божилов И., Владимир (Расате), [в:] Кирило-Методиевска енциклопедия, Т. І. София 1985.

Божилов И., Седем етюда по Средновековна история, София 1995.

Божилов И., Гюзелев В. История на средновековна България VII-XIV век, София 1999.

Бояджиев А., Св. Климент Охридски и кирилицата, [в:] Климент Охридски - живот и дело, София 2000, с. 86-111 (Кирило-Методиевски студии, 13).

Гильфердинг А., Собрание сочинений, Т. І., Санкт-Петербург 1868.

Георгиев Е., Разиветът на българската литература в IX-X в., София 1962.

Голубинский Е., Краткий очерк истории православных иерквей Болгарской, Сербской и Румынской или Молдо-Валашской, Москва 1871.

Гюзелев В., Княз Борис I. България през втората половина на IX в., София 1969. 
Добрев И., Кирило-методиевите ученици през първите години след пристигането им в България (886-893), [в:] Изследвания по кирило-методиевистика, София 1985, c. $155-159$.

Драгова Н., Нов прочит на епископската титулатура на св. Климент, [в:] Българи в Италия и италианщи в България. Приноси, София 1997.

Дринов М., Южные славяне и Византия в Х веке, «Чтения в Императорском Обществе Истории и Древностей Российских при Московском Университете» 1875 № 3.

Дринов, М. Избрани съчинения, Т. І. Трудове по българска и славянска история, София 1971.

Дуйчев И., Българско средновековие. Проучвания върху политическата и културната история на средновековна България, София 1972.

Златарски В., Страници из старата културна история на българите, [в:] Сборник в чест и в памет на Луи Леже 1843-1923, София 1925.

Златарски В., Образуване на българската народност, «Българска историческа библиотека» 1 (1928) T. I, с. 107-110.

Златарски В., Държавно-политическите идеи на иар Симеона, «Летопис на Българската академия на науките» Т. XII (1928/ 1929), София 1931, с. 195.

Златарски В., История на българската държава през средните векове. Т. І. История на Първото българско ияарство, Ч. 2. От славянизачията на държавата до падането на Първото ичарство (852-1018), Под ред. на П. Петров, София 1971.

Илиев И., Управлението на княз Расате (Владимир) (889-893). Един неуспешен опит за европейска преориентация във външната политика на България, [в:] Средновековна християнска Европа: Изток и Запад. Ценности, традииии, общуване, София 2002, с. 407-410.

Ильинский Г., Где, когда, кем и с какою иеелью глаголица была заменена «кириллицей»?, «Byzantinoslavica» III (1931), c. 87.

Иречек К., История болгар, Одесса 1878.

Каймакамова М., Старобългарската летописна традиция и «Повесть временных лет», [в:] Българско средновековие. Българо-съветски сборник в чест на 70-годишнината на проф. Иван Дуйчев, София 1980, с. 214-215.

Калиганов И., Болгарская литература, [в:] История литератур западных и южных славян, Т. І. Москва 1997.

Калоянов А., Славянската православна цииилизация. Началото: 28 март 894 г., Плиска, Велико Търново 2007.

Кочев Н., Народният събор в Преслав през 893/4 г., [в:] 1100 години Велики Преслав, Т. 1. Отг. ред. Т. Тотев, Шумен 1995, с. 52.

Кочев Н., Имало ли е Народен събор в Преслав през 893-894 г., «Духовна култура» 1993, c. 27.

Кирилло-Мефодиевский сборник. В память о совершившемся тысящелетии славянской письменности и христианства в России, изданный М. Погодиным. Москва 1865.

Лавров П., Кирило та Методій в давньо-слов'янському письменстві (Розвідка), Київ 1928. Лопарев Х., Чудо Святого Георгия о болгарине. Памятник византийской, переводной, литературы, Санкт-Петербург 1894 (Памятники древней письменности ИОЛДП, 100).

Љетопис попа Дукљанина. Увод, превод и коментар С. Мијушковић, Титоград 1967.

Мутафчиев П., История на българския народ (681-1323), Под ред. на В. Гюзелев, София 1986.

Николов А., Политическа мисъл в ранносредзновековна България (средата на IX-края на Хвек), София 2006.

Николов Г., Централизъм и регионализъм в ранносредновековна България (края на VII-началото на XI век), София 2005. 
Палаузов С., Век болгарского ичаря Симеона, Санкт-Петербург 1852.

Полывянный Д., Культурное своеобразие средневековой Болгарии в контексте византийско-славянской общности IX-XIV веков, Иваново 2000.

Помен за миналото, урок за настоящето, «Зора» X (15 V 1929) № 2959.

Славова Т., Глаголическата традиция и Преславската книжнина, «Palaeobulgarica» XXIII (1999) № 1, с. 35-46.

Соколов М., Из древней истории болгар, Санкт-Петербург 1879.

Срезневский И., Дополнения к общему повременному обозрению древних памятников русского письма и языка, II, «Известия Императорской Академии наук по Отделению Русского Языка и Словестности», Т. 10. Санкт-Петербург 1861-1863.

Станчев К., Попов Г., Климент Охридски. Живот и творчество, София 1988

Стефанов П., Юлиан Отстьпник и Владимир-Расате, [в:] 1100 години Велики Преслав, Т. 1. Отг. ред. Т. Тотев. Шумен 1995, с. 227-239.

Трифонов, Ю. Достоверен ли е разказът за ослепяването на Борисовия син Владимир?, «Училищен преглед» XXVI (1927) № 5-6, с. 864-890.

Турилов А., К изучению Сказания инока Христодула: датировка чикла и имя автора, [в:] Florilegium. К 60-летию Б. Н. Флори, Москва 2000.

Турилов А., «Мъдра Пльсковская» и «Мъдра Дръсторская»-две Мундраги первой болгаро-венгерской войны (география чудес вмч. Георгия в Сказании инока Христодула), [в:] Славяне и кочевой мир. К 75-летию акад. Г. Г. Литаврина, Москва 2001, с. 40-58 (Славяне и их соседи, 10).

Турилов А., Борис, [в:] Православная энциклопедия, Т. VI., Москва 2003, с. 30-32.

Филарет, Историческое учение об отиах иеркви, Т. I, Санкт-Петербург 1859.

Централен държавен архив - София, Ф. 3 к, Оп. 1.

Шепард Д., Неспокойни съседи. Българо-византийска конфронтация, обмен и съжителство през средните векове, Прев. Л. Генова, София, 2007

Annales Fuldenses sive Annales Regni Francorum Orientalis, post ed. G. H. Pertzii recognovit F. Kurze, Hannoverae 1891.

Bobcev S., Bulgaria under Tsar Simeon - II, «The Slavonic and East European Review» 8 (1929) № 22.

Bryer A., James Cochran Stevenson Runciman, [in:] Byzantine Style, Religion and Civilization. In Honour of Sir Steven Runciman, ed. by E. Jeffreys, Cambridge 2006, p. XIX.

Buc Ph., Ritual and Interpretation: the Early Medieval Case, «Early Medieval Europe» 9 (2000) № 2, p. 183-210, http://dx.doi.org/10.1111/1468-0254.00065.

Bührer-Thierry G., «Just Anger» or «Vengeful Anger»? The Punishment of Blinding in the Early Medieval West, [in:] Anger's Past. The Social Uses of an Emotion in the Middle Ages, ed by B. Rosenwein, Ithaca 1998.

Curta F., Southeastern Europe in the Middle Ages, Cambridge 2006 (Cambridge Medieval Textbooks, 39).

Eichler D., Frankische Reichsversammlungen unter Lüdwig dem Frommen, Hannover 2007 (Monumenta Germaniae Historica. Studien und Texte, 45).

Fine Jr. J. V. A., The Early Medieval Balkans. A Critical Survey from the Sixth to the Late Twelfth Century, Ann Arbor 1983.

Herrin J., Blinding in Byzantium, [in:] Polypleuros nous. Miscellanea für Peter Schreiner zu seinem 60. Geburtstag, Hrsg. von C. Scholz und G. Makris, München-Leipzig 2000, p. 56-68 (Byzantinisches Archiv, 19).

Lesne É., Les ordonnances monastiques de Louis le Pieux et la Notitia de servitio monasteriorum, «Revue d'histoire de l’Église de France» 6 (1920) № 32, p. 321-338.

Maclean S., Kingship and Politics in the Late Ninth Century. Charles the Fat and the end of the Carolingian Empire, Cambridge 2003. 
Milkova F., Les réunions du peuple en tant qu 'institution de l'État bulgare médiéval, «Études Balkaniques» 1978 № 4, p. 115-122.

Obolensky D., The Bogomils. A Study in Balkan Neo-Manichaeism, Cambridge 1948.

Obolensky D., The Byzantine Commonwealth. Eastern Europe, 500-1453, London 1971.

Reginonis abbatis Prumiensis Chronicon cum continuatione Treverensi, Recognovit Fr. Kurze, Hannoverae 1890.

Runciman S., A History of the First Bulgarian Empire, London 1930.

Shepard J., Symeon of Bulgaria - Peacemaker, «Годишник на Софийския университет. Научен център за славяно-византийски проучвания» «И. Дуйчев» 3 (1989), София 1991, p. 9-48.

Shepard J., Slavs and Bulgars, [in:] The New Cambridge Medieval History, vol. 2: c. 700-900, ed. by R. McKitterick, Cambridge 1995, p. 228-248.

Shepard J., Bulgaria: the other Balkan 'empire', [in:] The New Cambridge Medieval History, vol. 3: c. 900 - c. 1024, ed. by T. Reuter, Cambridge 1999, p. 567-585.

Soulis G., The Legacy of Cyril and Methodius to the Southern Slavs, «Dumbarton Oaks Papers» 19 (1965), p. 25.

Šafařjk P., Slowanské starožitnosti. Oddjl děgepisný, Praha 1837.

Vita Hludowici imperatoris, [in:] Monumenta Germaniae Historica. Scriptores, T. II, Hannoverae 1829.

Zlatarski V., The Making of the Bulgarian nation (II), «The Slavonic Review» 4 (1926) № 12, p. 640-644. 
